\title{
On the Question of Sustainable Forest Practices? An Assessment of Ghana's Ratification of the Voluntary Partnership Agreement
}

\author{
Gordon Kofi Sarfo-Adu \\ Forestry Commission, Corporate Planning Manager
}

\begin{abstract}
Between 2015 and 2020, the rate of deforestation was estimated at 10 million hectares per year. Continued forest degradation raises serious socio-economic and environmental concerns which has led to policy proposals emanating from both local and international sources. What would make a sovereign country kowtow to externally driven policy intervention? This study contributes to the literature on sustainable forest management by assessing why countries would ratify interventions that are proposed by parties external to the sovereign state. Being the first country to ratify the European Union Voluntary Partnership Agreement (VPA), this study assesses the rationale for Ghana's ratification of the VPA. The study adopts the qualitative case study design to purposively select key respondents who play critical roles in VPA value chain in Ghana. The study observes that although the VPA and its requirements are from external sources, they nonetheless fall in line with local ongoing efforts by the Forestry Commission of Ghana. The study concludes that a policy even if originates from external source is more likely to be embraced if does not challenge but feeds into government's prevalent activities, the legitimacy of that agreement/policy and enforcement remains higher. The study argues for a convergence of local and external interventions and the development of innovative mechanisms to effectively manage forests sustainably, to improve peoples' livelihoods, and protect natural resources.
\end{abstract}

Keywords: Sustainability; forest management; VPA; Policies; sustainable livelihoods

DOI: $10.7176 / \mathrm{JRDM} / 73-05$

Publication date: February $28^{\text {th }} 2021$

\subsection{Introduction}

Over the past five decades, the phenomenon of deforestation and forest degradation have been on the ascendency (FAO, 2015). The incessant pattern of deforestation exacerbates biodiversity loss and desertification with associated environmental challenges and threats to human lives (CBD, 2009; IPCC, 2007). This is because forests and ecosystems provide essential services including provisioning, regulatory and support services which all form the basis for livelihood (FAO, 2010). Continued deforestation and forest degradation therefore pose a major threat to the livelihood of the many communities dependent on forests, and to the economies of countries where forests and related resources are significant contributors to socio-economic development, as is the case in many developing countries.

To address the issue of forest loss, intergovernmental organizations, NGOs, and national governments have sought to roll out measures to maintain world's forests. Governments in most countries contend that national forest plans within the international forest policy arena remains crucial for sustainable forest management (McDonald \& Lane, 2004). The concept of governance is used to designate modern society's situation, whereby the policy process is subjugated by an array of diverse actors that depend on each other's cooperation (Rhodes, 1997). Thus, a network of actors rather than the government alone will make policy decisions and forge a vision and direction for forest sustainability (Boyle et al., 2001). Thus, if efforts to implement SFM are to succeed, it is important to consider several institutional aspects which include, inter alia, the process of consensus-building around the meaning of sustainable forest management and the process by which SFM practices become established in rules, actor networks and power (Meyer \& Baltes, 2004).

The extant literature adopts an institutional approach to assess how governments adopt peculiar governance regimes (Ayana et al, 2017; Yeboah-Assiamah et al, 2017); assess the impact of actor networks in sustainable management of forests (Kathrin, 2019; Johansson, 2018; Mohammed et al, 2017). But the question which still remains inconclusively addressed in the literature is: what propels a sovereign country to incorporate non-legally binding international institutional arrangement into its own institutional and management practices? It is imperative for the literature on sustainable forest management and institutionalism to fill this research gap by assessing the key drivers of such policy adoptions. In contemporary times, there are numerous non-legally binding forest regimes including the United Nations Forum on Forests (UNFF) which seek through voluntary means to help salvage forests. These non-legally binding regimes are voluntarily subscribed by countries who have different motivations for doing so. A typical example is the Voluntary Partnership Agreement by the EU to help address illegal logging and forest loss. The VPA is a bilateral agreement between the European Union (EU) and wood exporting countries. The initiative aims to improve forest governance and ensure that the wood imported into the EU has complied with the legal requirements of the partner country. The VPA is part of the European Union's action plan (Forest Law Enforcement Governance and Trade) to eliminate illegal timber from its market. If it non- 
binding, what then would make a sovereign country comply or incorporate these in their forest management practices? This current study seeks to contribute to the SFM literature by assessing the rationale and key drivers of non-legal binding international protocols using the case of Ghana and the VPA. Although voluntary and nonlegally binding, Ghana was the first country to sign up to the VPA and it crucial to assess the drivers or rationale.

\subsection{Theoretical Framework}

\section{Theoretical framework: policy arrangement approach}

In this research, the policy arrangement approach (PAA) was used to frame the study. The concept of policy arrangement suggests temporary stabilization of the content and organization of a particular policy domain (Van Tatenhove et al, 2000) involving structures formed through processes and interactions among policy actors and rules (Arts \& Leroy, 2006). This approach is more appropriate when a research hinges on the dimensions of actors, power, rules and discourse (Arts \& Van Tatenhove, 2004; Arts \& Leroy, 2006). The framework pays peculiar attention to (1) institutional contexts in which policy actors must operate, (2) the substance of policy-making and (3) the power relations between the policy actors involved (Wiering \& Arts, 2006). As this proposed study discusses impact of VPA implementation on governance and institutional structures of Ghana as well as impact on forest practices, the PAA framework is more appropriate to frame the study. this framework has been applied to analyze dynamics of forest policies elsewhere, including the Netherlands (Veenman et al, 2002), Belgium (Van Gossum et al, 2011) and South Korea (Park \& Youn, 2013).

The PAA as theoretical framework rests on two key philosophies; (i) political modernization and (ii) policy arrangements. Political modernization entails the ever-changing interactions between the state, the market and civil society in political domains of society within national borders and beyond which is manifested in through globalization and Europeanization (Arts \& Van Tatenhove, 2006). An implication is that forest decision processes do not rest with governments of one state or the traditional forest sector alone but polycentric in nature (Verbij, 2008).

The policy arrangement is discussed along following four dimensions: (a) actors and their coalitions involved in the policy domain; (2) the division of resources between these actors (b) the rules of the game and (d) discourses (Arts \& Goverde, 2006; Arts et al., 2006).

\section{0 Methodology}

The case study design within the qualitative research approach of social research was adopted for the study. The purposive sampling technique was used to select relevant informants to participate in the study. With qualitative study, researchers do not place much emphasis on numbers but the quality of information that would be elicited from participants (Sandelowski, 1995). Both primary and secondary sources of data were used to undertake the study. Primary data was elicited from respondents along the value chain of enforcing Ghana's VPA.

The purposive sampling technique was used to select fifty-nine (59) key actors from the Forestry Commission which is the lead government institution for VPA implementation in Ghana and expected to contribute about eighty per cent of VPA implementation. A newly created TVD at FC coordinates VPA implementation process. Key administrative and implementing officials of the relevant units/departments at the Forestry Commission; relevant committees/councils and working groups for VPA implementation and a VPA Secretariat as well as participants from the Ministry of lands and natural resources. Key actors from the Resource Management Support Centre (RMSC), the Forest Service Division (FSD) and the Timber Industry Development Division (TIDD) of Ghana's Forestry Commission were selected. Tropenbos International, a non-state organization which has been active in VPA processes was selected.

Secondary data involved data from journal sources, scholarly books, internet sources, published and unpublished materials relevant to the study. Again, documents from Ministry of lands and natural resources, Forestry Commission of Ghana; Ghana-EU team bulletins and other releases were resorted to.

The main instrument for primary data collection was through the use of in-depth interviews and semistructured questionnaires. In-depth interview involves face-to-face interaction with key respondents. Data was recorded and transcribed which was subsequently organized through thematic analysis.

\subsection{Data and Discussion}

\subsection{Pacesetter of VPA ratification: The rationale and driving force}

The section clearly illustrates that Ghana was among the first four countries to ratify the VPA agreement in the early years of 2007 although this initiative adopted by the EU was non-legally binding on sovereign timber exporting countries. The trajectory of its ratification among countries is illustrated in table 1.1 below. 
Table 1.1: Voluntary Partnership Agreement: Country Progress since 2007

\begin{tabular}{llll}
\hline Country & Negotiations began & VPA signed & VPA enforcement \\
$* * *$ Ghana & 2007 & 2009 & 2014 \\
Indonesia & 2007 & 2013 & 2011 \\
Cameroon & 2007 & 2010 & \\
Malaysia & 2007 & 2012 \\
Central African Republic & 2009 & 2011 & 2013 \\
Liberia & 2009 & & \\
Democratic Republic of the & 2010 & & \\
Congo & & & \\
Gabon & 2010 & & \\
Vietnam & 2010 & & \\
Guyana & 2012 & & \\
Côte d'Ivoire & 2013 & & \\
Thailand & 2017 & & \\
\hline
\end{tabular}

Adapted from: EFI, 2018

***First to sign VPA

\subsection{Rationale for VPA ratification in Ghana}

In an interview with 59 key actors in the enforcement of the VPA, all of them answered in the affirmative that the VPA remains essential and it is important for countries to sign on to the regime to foster sustainable governance of forests. The unanimous response on the value and relevance of the Voluntary Partnership Agreement is an indication that the inception of the programme was met with adequate legitimacy. The key informants provided many reasons to explain the rationale and usefulness of the VPA in the forest governance of Ghana. From in-depth discussion with key informants in the VPA process, it emerged that at least four reasons necessitated Ghana's decision to sign on to the VPA. The various themes coded from the field data are organized and discussed along the following theme and also illustrated in figure 1.1.

These reasons have been illustrated in a model below:

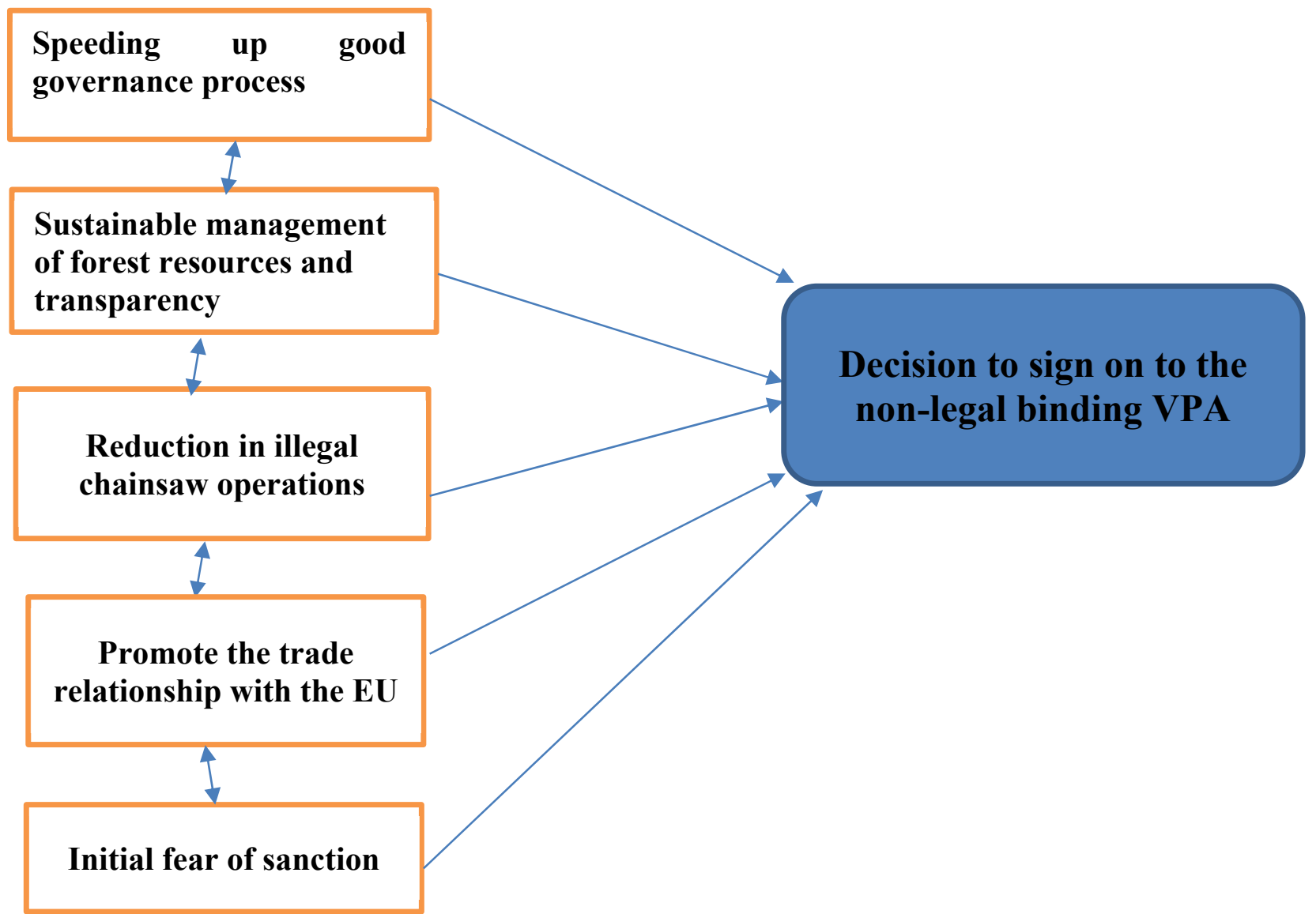

Fig 1.1: Reasons for Ghana's ratification of VPA 


\subsubsection{Speeding up good governance process}

Respondents sampled for the study indicated that the VPA was introduced by the EU and Ghana signed on to it with a view to enhancing its good governance process in the forestry sector. It was observed from interaction with respondents that Ghana's Forestry Commission had begun with its own internal processes of promoting transparency and waging a war on illegal logging. Therefore an external program by the EU which also fed into the already prevalent processes and intentions of the Forestry Commission to foster good governance was welcome in order to speed up the forest sector's good governance process. For example, an assistant manager at the Resource Management Support Centre of the Forestry Commission explained:

The VPA process is aimed at improving upon existing forest management systems and standards, therefore it feeds into what we had started already and so it sought to reinforce and strengthen what we had started already.

\subsubsection{Assist in sustainable management of forest resources and transparency}

It also emerged from the study that a major goal of Ghana's decision to ratify the EU VPA was to promote sustainable management of forest resources in the country. The idea of sustainable management of forest and timber has been a very important goal of government and a program which seeks to reinforce this objective was a welcoming news. This point was well explained by an assistant manager at the Resource Management Support Centre that the VPA is very relevant as a result of Ghana's trade relationship with the European Union and more importantly the program's quest to ensure sustainable forest management.

This position was given support by another personnel at the Resource Management Support Centre explained:

"legalizing aspects of timber trade from harvesting to export (as done in VPA) will contribute to sustainable forest management"

A senior officer with three and half decades' experience explained this by pointing out:

The VPA is very relevant in ensuring sustainable forest management in partner countries by ensuring timber harvested and exported is coming from legal source. It ensures full benefit and equity in the distribution of forest resources to forest owners and resource management.

By way of corroborating the foregoing argument, a forest range manager provided support to the sustainable forest management argument above. He explained:

The inception of the VPA has specifically reduced the high rate of illegal lumber on the timber market both local and international...the idea has been to issue verified legal timber products with FLEGT licence which will help curb illegal logging and will also help discourage individuals or companies that may encourage illegal logging.

\subsubsection{Reduction in illegal chain saw operations and forest degradation}

Closely related to the above point, the activities of illegal logging through chain saw operations has been on the ascendency and efforts at clamping down these activities had been slower and less motivating. Therefore, the inception of VPA was a way of rekindling and also to justify efforts at reducing illegal chain saw activities in the country. A key officer at the FC noted:

....Ghana's signing on to the VPA was because the program will help in the fight against illegal timber business

This point was given support by a manager at the GIS and Mapping Unit who noted:

The VPA is relevant to help ensure that the remaining timber resources within the country are harvested through legal means which will help ensure sustainability because will enhance the adequate enforcement of the forestry sector legal regime

\subsubsection{Ghana-EU trade relationship}

It emerged that the European Union has been the major trade partner with Ghana and the timber from Ghana has traditionally seen the EU market as its destination point. Henceforth, Ghana responded to the call to promote openness and transparency in the forestry sector in order to maintain her relationship with her strategic timber trading partner (EU). This point was suggested by all key informants who explained that sustaining the trade relationship was fundamental in Ghana's signing on to the VPA.

A senior official who has worked at the Forestry Commission for close to two decades' made this point:

"Ghana's ratification or signing on to the VPA is very important because it will facilitate continuous access to the EU market and will help secure additional funding for supporting sustainable forest management and to sustain Ghana's forest"

The foregoing point was corroborated by a manager at the RMSC who explained that the quest for a sustained access to the EU market necessitated Ghana's decision to join the VPA regime. He made this submission:

Ghan a conformed to the VPA process and signed on to the program in order to be able to make her wood products enjoy continued access to the European market.

The above point was corroborated by an experienced GIS officer with over three decades experience at the Forestry Commission who explained that it is not sustaining access to the EU market but more importantly to give timber 
products from Ghana a more competitive and attractive price at the global level. He explained:

The VPA has an added advantage of providing a strong bargaining power for timber resources within partner countries and to comply with international good practices within the forestry and environmental sector.

Providing support to the worldwide acknowledgment of timber from Ghana, a senior manager at the Forestry Commission expanded the scope of legitimacy to cover all international transactions. He made this submission:

The VPA facilitates the acknowledgment of the source of timber such that timber business will be more accepted in the international community which will help increase revenue.

In giving support to the foregoing point, an assistant manager at the Forestry Commission explained that:

"the VPA has been to strengthen the market position of Ghana's verified-legal timber products in the EU

market... and to raise the international profile of Ghana as it will highlight Ghana's efforts to improve transparency"

The reasons explained above point to the fact that the VPA was deemed crucial to Ghana's quest to foster effectiveness in the management of forest resources. In other words, local efforts at advancing transparency, openness and reducing deforestation or illegal lumbering got strengthened with the inception of VPA. This is to suggest that the VPA met local efforts and cumulatively sought to arrive at main overarching goal of sustainable governance of forest products.

\subsubsection{Market restriction}

Beyond the intrinsic desire to protect forest resources and to sustain forest management in Ghana, respondents also indicated that some form of fear and an apparent threat or conditionality inherent in the VPA process. Although not very explicit, it was implied and subtly embedded in the VPA model. A senior manager with two decades experience at the Forestry Commission opined:

There was the fear of being excluded from exporting timber to the EU market

This point was corroborated by a senior technical officer at the FC who argued:

The fear was that EU remained the main buyer of Ghana's timber products and the fact that if countries did not comply with VPA protocol will not have access to the EU market for our timber products was enough conditionality and threat

A senior officer explained that although Ghana was the first to sign on to the VPA, there was some form of hesitation and sense of fear among many stakeholders in the timber trade business. He made his submission:

Many were of the view that timber resources were too limited and VPA had little chance of success. Timber in many countries is harvested by small scale millers who would be displaced by the VPA when fully implemented. And for some countries, they felt they did not have the adequate logistics, skills and manpower to fully implement the VPA. Besides, the process was very cumbersome for both the small scale and large scale millers

However, a director of operations explained that Ghana did not hesitate in its decision to sign up to the VPA. He explained that some countries elsewhere may want to hesitate perhaps due to the initial cost of establishing the WTS, its maintenance and other key prerequisites to make the VPA more recognized and operational.

\subsection{Discussion}

Although non-legally binding, the VPA by EU was accepted by Ghana and ratified because those requirements fed into already existing local efforts by the Forestry Commission to promoting sustainable forest management and good governance in the forestry sector. The VPA uses more technologically enhanced efforts and processes to help in monitoring timber source and its value chain before final export which also reinforce the Forestry Commission's effort of promoting sustainable forest management. The findings of this study provide support to a proposition by Hickey and Nitschke (2007) that moving toward SFM requires improved governance and information reporting at the local, national, and international levels and put much emphasis on how the interplay of international agreements influence country level enforcement of Sustainable Forest Management.

The findings corroborate existing literature which demonstrate that when international agreements to do not challenge but feed into government's activities, the legitimacy of that agreement and enforcement remains higher. This has been advanced by Rutt et al (2018) who explain that the VPA's consideration of country sovereignty resonated well with the interests of governments as timber legality builds on domestic regulatory framework rather than on external or foreign set of rules, as in the case of non-state market forest certification schemes. To McDermott (2014), a policy that seeks to reinforce the sovereignty of government will be acceptable; he refers to it as a shift back to state power "re-embraces the role of governments", thereby promoting state authority and legitimacy (p. 15). Inspired by the US Lacey Act, with respect to the VPA and FLEGT, the EU parliament avoided precise definitions of "legality of timber". The EU legislation maintains, "In the absence of an internationally agreed definition, the legislation of the country where the timber was harvested, including regulations as well as the implementation in that country of relevant international conventions to which that country is party, should be the basis for defining what constitutes illegal logging (Cited in Cashore \& Stone, 2012, p.7) 


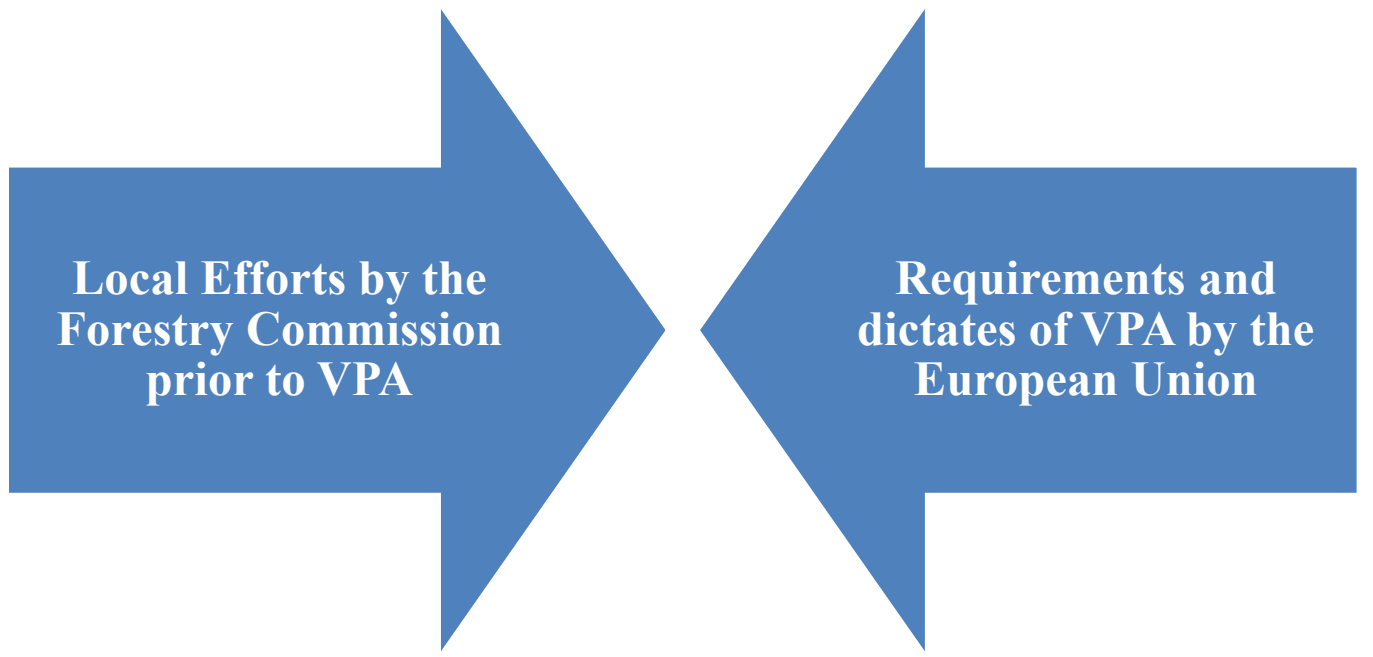

Figure 1.2: VPA requirements dovetailing into Local efforts

Source: Author's construct from field data

The VPA and Ghana's decision to sign on to it was to help address illegal logging and to foster sustainable forest management through partnership as noted in figure 1.2. In other words, although the VPA and its requirements are from external sources, they nonetheless fall in line with local ongoing efforts by the Forestry Commission. The observation resonates with what the Minister for Foreign Trade and Development in Finland stated in 2009 on VPAs, he explained that VPA "provides a novel and innovative mechanisms for supporting countries that wish to manage their forests better, improve peoples' livelihoods, and protect natural resources" (EFI, 2009). Indeed, in an interaction with key respondents, it emerged that the introduction of the VPA was seen as a major strategic boost to help augment forest resources governance in Ghana and her trade with the international community. This is because international trade in timber in combination with a good governance approach which involves the requirement of a multi-stakeholder process with participation of different sectors and civil society actors, has sought to position the Voluntary Partnership Agreement as "special and different from a typical bilateral trade agreement" (EFI, 2015; Owusu, 2009)

\subsection{Conclusions and policy implications}

From the study findings and discussions above, the following conclusions are drawn.

The study concludes that a policy even if originates from external source is more likely to be embraced if does not challenge but feeds into government's prevalent activities, the legitimacy of that agreement/policy and enforcement remains higher.

Secondly, the VPA is an external mechanism which has been localized and infused with ongoing projects to provide novel and innovative mechanisms for supporting Ghana's desires and quest to manage forests better, improve peoples' livelihoods, and protect natural resources

Thirdly, the VPA has established a policy and legality assurance, in its operationalization it has also established some remarkable structural and institutional processes to help in a comprehensive realization of its main objective of enhancing sustainable forest practices.

\section{REFERENCES}

Ayana, A. N., Vandenabeele, N., \& Arts, B. (2017). Performance of participatory forest management in Ethiopia: institutional arrangement versus local practices. Critical Policy Studies, 11(1), 19-38.

Cashore, B., \& Stone, M. W. (2012). Can legality verification rescue global forest governance?: Analyzing the potential of public and private policy intersection to ameliorate forest challenges in Southeast Asia. Forest policy and economics, 18, 13-22.

CBD (2009), Connecting Biodiversity and Climate Change Mitigation and Adaptation. Report of the Second Ad Hoc Technical Expert Group on Biodiversity and Climate Change. Montreal, Technical Series No. 41, 126 pages. www.cbd.int

EFI (2009). What Is a Voluntary Partnership Agreement?. Available at http://www.euflegt.efi.int/documents/10180/23013/EFI+Policy+Brief+3++What+is+a+Volunta y+Partnersh p+Agreement/076495d8-741e-49da-aeaf-b67e2d3d2239 (Accessed on 12 January, 2018)

European Forest Institute (2018). What is a Voluntary Partnership Agreement? - the European Union Approach. Available at https://www.efi.int/

FAO (2010). Biodiversity for Food and Agriculture Contributing to food security and sustainability in a changing 
world. Available at http://www.fao.org/fileadmin/templates/biodiversity paia/PAR-FAO book lr.pdf (Accessed on 12 January, 2018)

FAO (2015). Global Forest Resources Assessment 2015. Available at http://www.fao.org/3/a-i4808e.pdf. (Accessed on 12 January, 2018)

Hansen, C. P., Rutt, R., \& Acheampong, E. (2018). 'Experimental' or business as usual? Implementing the European Union Forest Law Enforcement, Governance and Trade (FLEGT) Voluntary Partnership Agreement in Ghana. Forest Policy and Economics, 96, 75-82.

Hickey, G. M., \& Nitschke, C. R. (2007). Monitoring sustainable forest management in the Pacific Rim Region. Journal of Sustainable Forestry, 24(2-3), 245-278.

IPCC (2007), Fourth Assessment Report. International Panel on Climate Change. Available at https://www.ipcc.ch/assessment-report/ar4/ (Accessed on 12 January, 2018)

Johansson, J. (2018). Collaborative governance for sustainable forestry in the emerging bio-based economy in Europe. Current Opinion in Environmental Sustainability, 32, 9-16.

Kathrin, B. (2019). Collaborative governance in the making: Implementation of a new forest management regime in an old-growth conflict region of British Columbia, Canada. Land Use Policy, 86, 43-53.

McDermott, C. L. (2014). REDDuced: From sustainability to legality to units of carbon-The search for common interests in international forest governance. Environmental Science \& Policy, 35, 12-19.

Mohammed, A. J., Inoue, M., \& Shivakoti, G. (2017). Moving forward in collaborative forest management: Role of external actors for sustainable Forest socio-ecological systems. Forest policy and economics, 74, 13-19.

Overdevest, C., \& Zeitlin, J. (2018). Experimentalism in transnational forest governance: implementing European Union forest law enforcement, governance and trade (FLEGT) voluntary partnership agreements in Indonesia and Ghana. Regulation \& Governance, 12(1), 64-87.

Owusu, B. (2009). The dynamics of multi-stakeholder processes in the negotiation of voluntary partnership agreement in Ghana (Doctoral dissertation, Wageningen University-Department of Social Sciences).

Rutt, R. L., Myers, R., Ramcilovic-Suominen, S., \& McDermott, C. (2018). FLEGT: Another 'forestry fad'?. Environmental Science \& Policy, 89, 266-272.

Wodschow, A., Nathan, I., \& Cerutti, P. (2016). Participation, public policy-making, and legitimacy in the EU Voluntary Partnership Agreement process: The Cameroon case. Forest Policy and Economics, 63, 110.

Yeboah-Assiamah, E., Muller, K., \& Domfeh, K. A. (2017). Institutional assessment in natural resource governance: A conceptual overview. Forest policy and economics, 74, 1-12. 